Tropical Journal of Pharmaceutical Research March 2019; 18 (3): 611-617

ISSN: $1596-5996$ (print); 1596-9827 (electronic)

(C) Pharmacotherapy Group, Faculty of Pharmacy, University of Benin, Benin City, 300001 Nigeria.

\title{
Bioactivity, nutritional property, and rapid chemical characterization of aqueous extract of Annona muricata leaf from Mexico
}

\author{
Ana V Coria-Téllez ${ }^{1 *}$, Eva N Obledo-Vázquez\#, Eduardo Padilla-Camberos ${ }^{2}$, \\ Marisela González-Ávila², Moisés Martínez-Velázquez ${ }^{2}$ \\ ${ }^{1}$ Laboratorio de Análisis y Diagnóstico del Patrimonio, El Colegio de Michoacán, A.C., 59379, Michoacán, ${ }^{2}$ Centro de \\ Investigación y Asistencia en Tecnología y Diseño del Estado de Jalisco, A.C., 44270, Jalisco, México
}

${ }^{*}$ For correspondence: Email: anac@colmich.edu.mx; Tel/Fax: +52-352-5256107

\begin{abstract}
Purpose: To investigate the bioactive and nutritional properties, as well as rapid chemical characterization of aqueous extract of Annona muricata leaf from Mexico

Methods: The crude aqueous extract of $A$. muricata leaf was obtained by decoction. Cytotoxicity was tested against cervicouterine cancer cells (HeLa) using methyl thiazol tetrazolium (MTT) assay. Antioxidant activity was evaluated using 2, 2-diphenylpicrylhydrazyl (DPPH) assay. Nutritional evaluation was carried out according to Association of Official Analytical Chemists (AOAC) procedures. Rapid qualitative chemical characterization of the extract was carried out by direct analysis in real-time mass spectrometry (DART-MS) method.

Results: The aqueous extract of A. muricata leaf showed cytotoxicity against HeLa cells and also antioxidant activity in a concentration-dependent manner. Nutritional analysis revealed the presence of carbohydrates, vitamin $\mathrm{C}, \mathrm{Na}$, and $\mathrm{Fe}$ in the aqueous extract. DART-MS spectra showed the presence of alkaloids and phenols as the major components.

Conclusion: The cytotoxic and antioxidant activities of the aqueous extract of A. muricata leaf lend some support for its traditional uses as anti-cancer remedy. These activities are probably due to its active secondary metabolites. Thus, the aqueous extract is a source of healthy nutritional components as well as a potential anti-cancer agent for humans.
\end{abstract}

Keywords: Annona muricata, Antioxidant activity, Cytotoxicity, DART-MS, Nutritional composition, Sour sop

\begin{abstract}
This is an Open Access article that uses a funding model which does not charge readers or their institutions for access and distributed under the terms of the Creative Commons Attribution License (http://creativecommons.org/licenses/by/4.0) and the Budapest Open Access Initiative (http://www.budapestopenaccessinitiative.org/read), which permit unrestricted use, distribution, and reproduction in any medium, provided the original work is properly credited.

Tropical Journal of Pharmaceutical Research is indexed by Science Citation Index (SciSearch), Scopus, International Pharmaceutical Abstract, Chemical Abstracts, Embase, Index Copernicus, EBSCO, African Index Medicus, JournalSeek, Journal Citation Reports/Science Edition, Directory of Open Access Journals (DOAJ), African Journal Online, Bioline International, Open-J-Gate and Pharmacy Abstracts
\end{abstract}

\section{INTRODUCTION}

Annona muricata $\mathrm{L}$. is an important tropical species from the family of Annonaceae, and the most commercialized and cultivated species of the genus Annona. In areas where A. muricata is grown, it is traditional to use infusion or decoction of its leaves as remedies for various conditions such as insomnia, catarrh, rheumatism, intestinal parasitic infections, diabetes, hypertension, asthma, gastrointestinal disorders, and cancer 
$[1,2]$, The last three traditional applications have been used in México [2].

The use of $A$. muricata to treat cancer has motivated some researchers to study the phytochemicals components and the bioactivity of extracts from this plant. The principal bioactive compounds have been identified from organic extracts of $A$. muricata leaf using chromatographic methods [1 - 5] . New advances in molecular ionization within mass spectrometry have allowed the rapid chemical profiling of plant species and their extracts sometimes without the need for sample preparation [6]. An example of this procedure is Direct Analysis in Real Time Mass Spectrometry (DART-MS) [7].

Some cytotoxic studies of aqueous extract of this plant have been conducted using leaves of the plant from Ivory Coast [8], and Ghana [9] against A375, and BPH-I cell lines, respectively. However, no studies have been reported for $A$. muricata leaf from Mexico. In the studies reported, the aqueous extracts showed less cytotoxicity than the organic extracts. The difference was attributed to variabilities in bioactive compounds present in plant extracts [2]. For this reason, in order to validate its traditional use as an anticancer agent, the aqueous extract of $A$. muricata leaf was studied for its cytotoxic and nutritional effects, in addition to its rapid chemical characterization of the extract.

\section{EXPERIMENTAL}

\section{Plant material}

A. muricata leaves were collected from a commercial farm located in Compostela, Nayarit, Mexico, $\left(21^{\circ} 14^{\prime} 14^{\prime \prime} \mathrm{N}^{\prime}, 105^{\circ} 12^{\prime} 42.183^{\prime \prime}\right.$ at $860 \mathrm{~m}$ elevation) in August 2012. The plant was identified by a taxonomist, Ignacio García, at the Centro de Investigación Interdisciplinario para el Desarrollo Integral de la Región (CIIDIR) del Instituto Politécnico Nacional (IPN). A voucher specimen was deposited at CIMI herbarium of the CIIDIR-IPN Michoacán (voucher number: 011301). The leaves were dried for three days at $40{ }^{\circ} \mathrm{C}$ to $7.6 \%$ humidity, and ground power. The powered sample was kept in plastic bags at room temperature in the dark, and vacuum-packed.

\section{Preparation of aqueous extract}

The aqueous extract of $A$. muricata leaf was prepared by decoction of $200 \mathrm{~g}$ of dried, powered leaves in $10 \mathrm{~L}$ of distilled water for $10 \mathrm{~min}$. The decoction was evaporated under vacuum conditions at $40-45{ }^{\circ} \mathrm{C}$ in a Buchi rotavapor until $10 \%$ of the original volume was left. The extract was kept at $-80^{\circ} \mathrm{C}$ until analyzed.

\section{Cell viability assay}

The MTT assay was used to measure the cytotoxic activity of the extract against HeLa cells. The HeLa cells were maintained in Gibco ${ }^{\text {TM }}$ Dulbecco's Modified Eagle Medium (DMEM) supplemented with $10 \%(\mathrm{v} / \mathrm{v})$ of $\mathrm{Gibco}^{\mathrm{TM}}$ fetal bovine serum at $37{ }^{\circ} \mathrm{C}$ in a humidified atmosphere containing a $5 \%(\mathrm{v} / \mathrm{v}) \mathrm{CO}_{2}$. The cells were seeded in 96-well plates at a density of $1 \times 10^{4}$ cells/well, and exposed to various concentrations of aqueous extract (0.38 to 7.6 $\mathrm{mg} / \mathrm{mL}$ ) for $24 \mathrm{~h}$. The cells were also treated with $2 \mu \mathrm{L}$ of serial dilution of cisplatin (positive control) and DMSO (negative control). At the end of the treatment time, the medium in each well was replaced with $100 \mu \mathrm{L}$ MTT $(5 \mathrm{mg} / \mathrm{mL})$, followed by incubation at $37^{\circ} \mathrm{C}$ for $4 \mathrm{~h}$. The reaction was stopped by adding $100 \mu \mathrm{L}$ DMSO to each well to dissolve the purple-blue MTT formazan crystals formed. The absorbance of each solution was read in a microplate spectrophotometer (XMark, BIORAD) at $590 \mathrm{~nm}$. The results were expressed as half-maximal inhibitory concentration $\left(\mathrm{IC}_{50}\right)$ which was calculated by Probit method using the statistical program, SAS system [10].

\section{Antioxidant activity}

The antioxidant property of the extract was determined with DPPH free radical scavenging methods assay (microplate method) [11]. From the stock solution of the aqueous extract, various dilutions (76, 152, 301, 456, 608, 760 and 912 $\mu \mathrm{g} / \mathrm{mL}$ ) were prepared and used for the DPPH assay. Absorbance was measured on a Cary 50 UV-VIS (Varian, Inc., CA, US) spectrophotometer and the $\mathrm{IC}_{50}$ was calculated from the calibration curve.

\section{Nutritional characterization}

Standard procedures described by AOAC (1984) [12] were using for nutritional characterization of dried and powered leaves of $A$. muricata, as well as the aqueous extract. Moisture content was evaluated using a drying oven, while protein content was estimated with Kjeldahl method. The fat content was measured with Soxhlet method, the ash analysis was evaluated by incineration in a muffle oven, while the carbohydrate content was estimated by subtraction of the sum of the protein, fat and ash contents. Crude fiber was measured by incineration after acid and base digestion. Dietary fiber determined using enzymatic gravimetric method. Vitamin C content 
was determined volumetrically. Vitamin A was estimated with HPLC, while total reducing sugars were measured with the Lans-Eyno method. The levels of $\mathrm{Ca}, \mathrm{Fe}$, and $\mathrm{Na}$ were estimated using inductively coupled plasma atomic emission spectroscopy (ICPES). Lixiviation efficiency (Le) from the leaves of $A$. muricata leaves was calculated as shown in Equation 1.

Le $(\%)=\mathrm{Na} / \mathrm{NI} \times 100$

where $\mathrm{Na}$ and $\mathrm{Nl}$ are the nutrient content of aqueous extract and leaves, respectively.

The total polyphenols content of the aqueous extract was estimated using the Folin-Ciocalteu method. The results are expressed as gallic acid equivalents (GAE mg/g of dry plant extract), using a gallic acid standard calibration curve (400 and $2000 \mu \mathrm{g} \mathrm{GAE} / \mathrm{mL}$ ) [4].

\section{Phytochemical characterization}

The phytochemical profile of the extract was recorded on a DART-MS (JEOL-AccuTOF JMST100LC). The DART-MS was operated with a resolving power of 6000 (full-width at halfmaximum). The DART ion source was operated with helium gas at $400{ }^{\circ} \mathrm{C}$ at a flow rate of approximately $4.0 \mathrm{~L} / \mathrm{min}$. A mass spectrum of polyethylene glycol (PEG) 600 solution was used as reference standard for exact mass calibration. The PEG solution and the extract were positioned in the gap between the DART source and mass spectrometer for measurements and, were introduced into the DART Helium plasma using the closed end of a borosilicate glass melting point capillary tube [6,7]. Each sample was introduced to the DART ion source three times. The elemental composition of selected peaks were determined using the Mass Centre Main software (version 1.3m; JEOL Japan).

\section{Statistical analysis}

The experimental data are presented as mean \pm standard deviation of three replicates in two independent experiments for cytotoxicity, and three replicates for antioxidant activity, total polyphenols quantification, proximate composition and mineral composition analyses.

\section{RESULTS}

\section{Cytotoxic effect of aqueous extract}

The aqueous extract of $A$. muricata leaf decreased the viability of HeLa cells in a concentration-dependent manner. The $\mathrm{IC}_{50}$ of the extract was $2.42 \mathrm{mg} / \mathrm{mL}$. It was almost 300 times less cytotoxic than the positive control cisplatin which had an $\mathrm{IC}_{50}$ of $0.0084 \mathrm{mg} / \mathrm{mL}$.

\section{Antioxidant activity of aqueous extract}

At the lowest concentration evaluated (76 $\mu \mathrm{g} / \mathrm{mL})$, the extract inhibited $30 \%$ of $\mathrm{DPPH}$, while a complete inhibition of DPPH was observed with extract concentration of 912 $\mu \mathrm{g} / \mathrm{mL}$. These results suggest that the extract scavenged DPPH free radicals in a concentration-dependent manner. The $\mathrm{IC}_{50}$ of the extract was $149.01 \mu \mathrm{g} / \mathrm{mL}$.

\section{Nutritional characterization}

The proximate composition and mineral components are present in the leaves of $A$. muricata and its aqueous extract are shown in Table 1. The leaves of $A$. muricata had carbohydrates as the major components, while fat, fiber, proteins and minerals were present as minor components. Only a portion of each component was lixiviated in the aqueous extract of the leaves. The principal components lixiviated from the leaves were: reducing sugars (41.6\%), vitamin C (36.9\%) and sodium (21.1\%). Other compounds lixiviated in a minor proportion were dietary fiber (14.8\%), proteins $(7.0 \%)$, carbohydrates (4.3\%), and ash (10.3\%). Among the minerals, only sodium was lixiviated in an appreciable quantity $(21.4 \%)$. The content of the total polyphenols in the extract was $63.1 \pm 0.93$ $\mathrm{mg} \mathrm{GAE} / \mathrm{g}$, as determined using Folin-Ciocalteu method.

\section{Composition and mass spectra of aqueous extract}

In the DART-MS spectrum of the extract in positive ionization mode (Figure 1A) 34 signals were observed but only 13 of them were related to some chemical compounds (Table 2). The principal compounds identified were carbohydrate-related compounds, alkaloids and phenols.

In the DART-MS spectrum of the extract in negative ionization mode (Figure 1B), only seven signals were observed (Table 3 ). These signals were related to carbohydrate related compounds, organic acids and a flavone. The most intense signal corresponded to an organic acid.

\section{DISCUSSION}

This is the first report on the inhibition of HeLa cells by an aqueous extract of $A$. muricata leaf. Previous reports showed higher cytotoxicity than what was obtained here. In the present study, the 

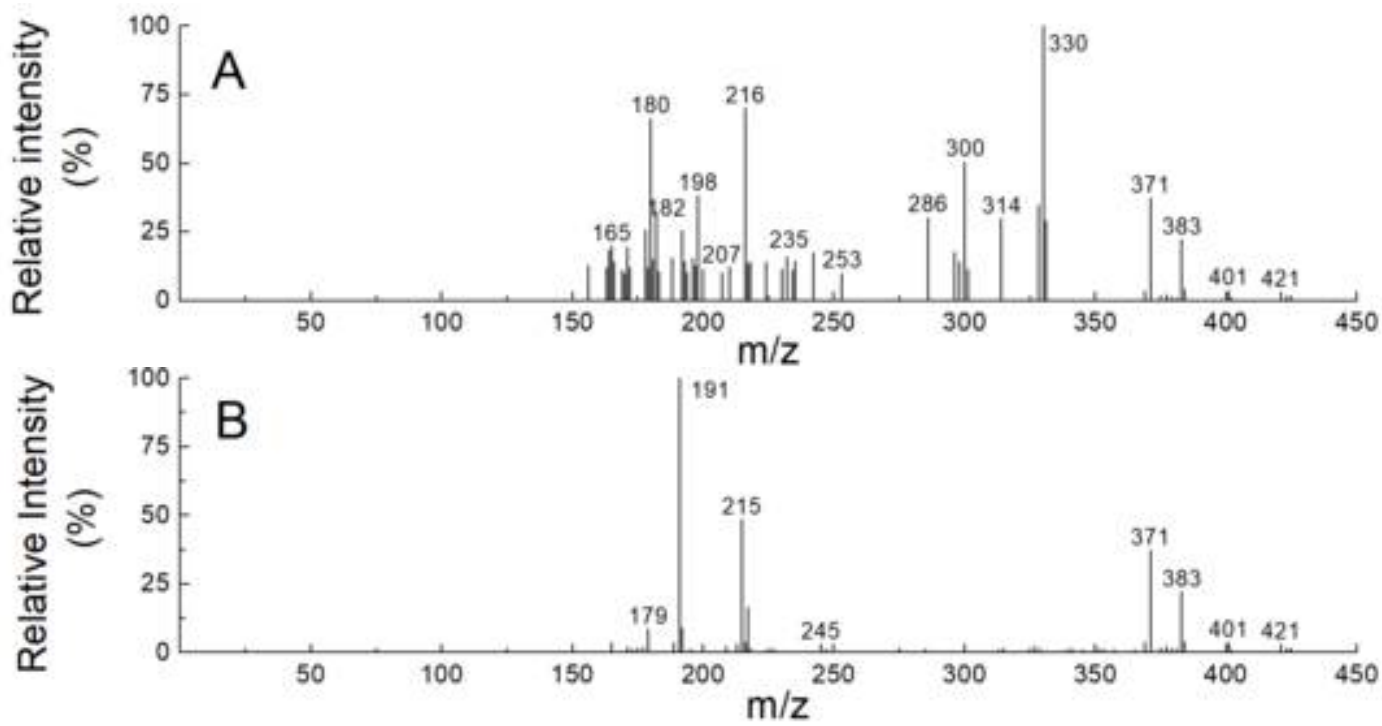

Figure 1: Representative DART-MS spectrum of aqueous extract of $A$. muricata leaf in positive ionization mode (A) and in negative ionization mode (B)

Table 1: Nutritional composition of Annona muricata leaves and its aqueous extract

\begin{tabular}{|c|c|c|c|}
\hline Nutrient & A. muricata leaf & $\begin{array}{l}\text { Aqueous extract } \\
\text { of } A \text {. muricata } \\
\text { leaf }\end{array}$ & $\begin{array}{c}\text { Lixiviation efficiency } \\
(\%) \text { of components from } \\
\text { leaves into aqueous extract }\end{array}$ \\
\hline Moisture (\%) & 4.95 & 95.18 & - \\
\hline Protein (\%) & 11.43 & 0.80 & 7.0 \\
\hline Ash (\%) & 7.50 & 0.77 & 10.3 \\
\hline Fat (\%) & 0.41 & $<0.10$ & - \\
\hline Saturated fat (\%) & 0.20 & $\mathrm{Nd}$ & - \\
\hline Total carbohydrate (\%) & 75.71 & 3.25 & 4.3 \\
\hline Total reducing sugar (\%) & 1.61 & 0.67 & 41.6 \\
\hline Dietary fiber (\%) & 5.42 & 0.80 & 14.8 \\
\hline Vitamin A (U.I./100g) & 5375.09 & 13.06 & 0.2 \\
\hline Vitamin C (mg/100g) & 6.48 & 2.39 & 36.9 \\
\hline Sodium $(\mathrm{mg} / 100 \mathrm{~g})$ & 38.20 & 8.19 & 21.4 \\
\hline Calcium (mg/100g) & 1220.00 & 0.082 & $<0.01$ \\
\hline Iron (mg/100g) & 3.05 & $<1.00$ & - \\
\hline Calorie (Kcal/100g) & 35.00 & 16.20 & 46.3 \\
\hline
\end{tabular}

Nd: not detected

$\mathrm{IC}_{50}$ of the aqueous extract against HeLa cells was $(2.42 \mathrm{mg} / \mathrm{mL})$, while in previous studies, the $\mathrm{IC}_{50}$ against $\mathrm{A} 375$ cells was $>0.5 \mathrm{mg} / \mathrm{mL}[8]$, and the $\mathrm{IC}_{50}$ against $\mathrm{BPH}-\mathrm{I}$ cells was $1.36 \mathrm{mg} /[9]$.

On the other hand, organic extracts of $A$. muricata have shown more cytotoxic effects than the aqueous extract. For example, the $I_{50}$ obtained here is 25 times less cytotoxic than the $I_{50}(0.097 \mathrm{mg} / \mathrm{mL})$ previously reported for the ethanol extract of $A$. muricata [13]. The lower cytotoxicity of the aqueous extract maybe due to the low water solubility of bioactive components of the plant [14]. It has been suggested that the growth inhibition of the cancer cells by ethanolic extract of $A$. muricata occurs through the disruption of mitochondrial membrane potential, reactive oxygen species (ROS) generation and the G0/G1 cell cycle arrest [15]. In particular, the cytotoxic activity was attributed to flavonoids and phenols [15]. Some of these compounds were detected in the DART-MS spectrum of the aqueous extract in the present study. These compounds are probably responsible for the observed cytotoxicity. Since the cytotoxic activity of the extract was evaluated in a single dose assay, therefore long-term assessments are necessary in order to identify the effect of the extract when other doses are administrated such as it happens in traditional medicine.

The antioxidant activity of the extract, evaluated using the DPPH inhibition method, was higher $\left(\mathrm{IC}_{50}=149.01 \mu \mathrm{g} / \mathrm{mL}\right)$ than that reported by Gavamukulya et al $\left(\mathrm{IC}_{50}=907 \mu \mathrm{g} / \mathrm{mL}\right)$ [16]. It has been suggested that the phenolic compounds are responsible for most of the antioxidant activities of plant extracts [4]. It is possible that the antioxidant activity of the aqueous extract is due to its polyphenol and vitamin contents. The 
Table 2: Composition of $A$. muricata aqueous extract determined with DART-MS in positive ionization mode

\begin{tabular}{|c|c|c|c|c|c|}
\hline $\begin{array}{l}\text { Measured } \\
\text { Mass (m/z) }\end{array}$ & $\begin{array}{l}\text { Calculated } \\
\text { mass }\end{array}$ & $\begin{array}{l}\text { Molecular } \\
\text { formula }\end{array}$ & Remarks & Type of compound & Reference \\
\hline 164.0724 & 163.172 & $\mathrm{C}_{6} \mathrm{H}_{13} \mathrm{NO}_{4}$ & DNJ o DMJ o DMDP & Alkaloid & [17] \\
\hline 165.0581 & 164.1580 & $\begin{array}{l}\mathrm{C}_{9} \mathrm{H}_{8} \mathrm{O}_{3} \\
\mathrm{C}_{10} \mathrm{H}_{12} \mathrm{O}_{2}\end{array}$ & $\begin{array}{c}\text { p-Coumaric acid } \\
\text { Eugenol }\end{array}$ & $\begin{array}{l}\text { Phenolic acid } \\
\text { Phenol }\end{array}$ & {$[22,23]$} \\
\hline 171.148 & 170.1195 & $\mathrm{C}_{7} \mathrm{H}_{6} \mathrm{O}_{5}$ & Gallic acid & Phenolic acid & {$[4]$} \\
\hline 180.0975 & - & - & - & Carbohydrate related & [24] \\
\hline 181.1304 & 180.1012 & $\mathrm{C}_{9} \mathrm{H}_{8} \mathrm{O}_{4}$ & Caffeic acid & Phenolic acid & [25] \\
\hline 198.1041 & - & $\mathrm{C}_{6} \mathrm{H}_{12} \mathrm{O}_{6}$ & - & Carbohydrate related & {$[7,24,26]$} \\
\hline 200.1071 & - & - & - & - & \\
\hline 207.1597 & 207.2010 & $\mathrm{C}_{12} \mathrm{H}_{14} \mathrm{O}_{3}$ & Chavibetol acetate $^{a}$ & Phenyl-propanoid & [22] \\
\hline 235.1901 & 234.2478 & $\mathrm{C}_{13} \mathrm{H}_{14} \mathrm{O}_{4}$ & $\begin{array}{l}\text { Allylpyrocatechol } \\
\text { diacetate }^{\mathrm{a}}\end{array}$ & Phenyl-propanoid & [22] \\
\hline 242.1055 & - & - & - & - & - \\
\hline 286.1518 & $\begin{array}{l}286.2363 \\
285.3376\end{array}$ & $\begin{array}{l}\mathrm{C}_{15} \mathrm{H}_{10} \mathrm{O}_{6} \\
\mathrm{C}_{17} \mathrm{H}_{19} \mathrm{NO}_{3}\end{array}$ & $\begin{array}{l}\text { Kaempferol } \\
\text { Coclaurine }\end{array}$ & $\begin{array}{l}\text { Flavonoid } \\
\text { Alkaloid }\end{array}$ & [5] \\
\hline 296.1486 & 295.3755 & $\mathrm{C}_{19} \mathrm{H}_{21} \mathrm{NO}_{2}$ & Xilopine & Alkaloid & [18][5] \\
\hline 298.1755 & 297.3483 & $\mathrm{C}_{18} \mathrm{H}_{19} \mathrm{NO}_{3}$ & Stepharine & Alkaloid & [3] \\
\hline 300.1682 & 299.3642 & $\mathrm{C}_{18} \mathrm{H}_{21} \mathrm{NO}_{3}$ & $\mathrm{~N}$-methylcoclaurine & Alkaloid & [19] \\
\hline 301.1808 & 300.4335 & $\mathrm{C}_{17} \mathrm{H}_{32} \mathrm{O}_{4}$ & $\begin{array}{l}\text { 1,13-tridecanediol, } \\
\text { diacetate }\end{array}$ & Ester & [27] \\
\hline 328.019 & 327.3743 & $\mathrm{C}_{19} \mathrm{H}_{21} \mathrm{NO}_{4}$ & $\begin{array}{l}\text { Isoboldine } \\
\text { Coreximine }\end{array}$ & Alkaloid & $\begin{array}{c}{[19]} \\
{[3]}\end{array}$ \\
\hline 330.1817 & 329.3902 & $\mathrm{C}_{19} \mathrm{H}_{23} \mathrm{NO}_{4}$ & Reticuline & Alkaloid & [3] \\
\hline
\end{tabular}

${ }^{a}$ Compound identified in other plant species using DART-MS

Table 3: Composition of $A$. muricata aqueous extract determined with DART-MS in negative ionization mode

\begin{tabular}{|c|c|c|c|c|c|}
\hline $\begin{array}{l}\text { Measured } \\
\text { Mass (m/z) }\end{array}$ & $\begin{array}{c}\text { Calculated } \\
\text { mass }\end{array}$ & $\begin{array}{l}\text { Molecular } \\
\text { formula }\end{array}$ & Remarks & Type of compound & Reference \\
\hline 179.0472 & 180.1558 & $\mathrm{C}_{6} \mathrm{H}_{12} \mathrm{O}_{6}$ & Hexose $^{a}$ & Carbohydrate related & [26] \\
\hline 191.0457 & $\begin{array}{l}192.1586 \\
192.0197\end{array}$ & $\begin{array}{l}\mathrm{C}_{7} \mathrm{H}_{11} \mathrm{O}_{6} \\
\mathrm{C}_{6} \mathrm{H}_{8} \mathrm{O}_{7}\end{array}$ & $\begin{array}{l}\text { Quinic acid } \\
{\text { Citric } \text { acid }^{\mathrm{a}}}^{\text {a }}\end{array}$ & Organic acid & {$[26,27]$} \\
\hline 215.0194 & - & $\mathrm{C}_{12} \mathrm{H}_{7} \mathrm{O}_{4}$ & na & - & [25] \\
\hline 371.0973 & 371.3145 & $\mathrm{C}_{20} \mathrm{H}_{20} \mathrm{O}_{7}$ & Tangeretin & Flavone & [4] \\
\hline 383.0933 & - & $\mathrm{C}_{14} \mathrm{H}_{23} \mathrm{O}_{12}$ & na & - & [27] \\
\hline
\end{tabular}

$\mathrm{Na}=$ not assigned; ${ }^{2}$ Compound identified in other plant species using DART-MS

total polyphenolic content of the aqueous extract $(63.1 \pm 0.93 \mathrm{mg} \mathrm{GAE} \mathrm{g})$ is higher than the one reported for a decoction of the leaves collected from the plant in India (47.75 mg GAE/g) [4]. The other antioxidant compounds are the vitamins. In this study an appreciable amount of vitamin $\mathrm{C}$ was lixiviated $(36.88 \%)$ from the $A$. muricata leaves into the aqueous extract, probably due to the water solubility of this vitamin.

In addition to vitamin $\mathrm{C}$, other components that were widely lixiviated from $A$. muricata leaves were reducing sugars $(41.61 \%)$ and sodium $(21.13 \%)$, while components with lower degree of lixiviation, but were present in important quantities in the extract were vitamin $A$, total carbohydrates, protein, ash, and dietary fiber. These findings suggest that the ingestion of the aqueous is rich in macro and micronutrients.

A rapid chemical profiling of the extract was obtained with the direct introduction of the sample into DART ionization camera. The DART-
MS spectrum signals were assigned to some of the expected phytochemical components that had previously been reported for this plant or for other plant species. Some signals such as $\mathrm{m} / \mathrm{z}$ 196, 215 and 383 have been found in other plant species but have not been related to any phytochemical compounds. On the other hand, a peak signal can be related to more than one molecule because they have the same molecular mass. Therefore, it was not possible to distinguish them from DART mass spectrum alone. This happened with DNJ/ DMJ/ DMDP (m/z 164), p-coumaric acid/eugenol (m/z 165), xilopine/argentinine $(\mathrm{m} / \mathrm{z} \quad 296), \quad$ and isoboldine/coreximine ( $\mathrm{m} / \mathrm{z} 328)$.

Using a sample standard, the most intensive signals such as m/z 198 has been reported as the ammonium adduct of monosaccharide using a sample standard [7]. The signal at $\mathrm{m} / \mathrm{z} 180$, assigned as carbohydrate-related, is one of the most abundant signals in DART-MS. The carbohydrates also were the principal 
components in the nutritional characterization of the aqueous extract.

Few chemical analyses have been conducted using a water solvent extract. In the DART-MS spectrum of the aqueous extract some signals were related to the principal alkaloids reported for $A$. muricata: reticuline [3], DNJ [17] coclaurine and xilopine [18]; argentinine [5], stepharine [3], and $\mathrm{N}$-methycoclaurine [19]. Reticuline has been shown to exhibit cytotoxic and antitumor potential [20]. Argentinine, an alkaloid [5], and the kaempferol, a phenolic compound, which were identified in the DART-MS spectrum of the aqueous extract, have been reported to possess antioxidant and cytotoxic activities [5]. Other phenolic compounds identified in the DART spectrum were the caffeic acid, gallic and pcoumaric acid. These phenolic acids occur naturally in their free forms in almost every plant species [21]. In addition, the flavone tangeretin which was identified in the DART spectrum was previously identified in the aqueous extract from A. muricata leaf using the HPLC method [4]. It has been reported that acetogenins are the principal bioactive compounds of $A$. muricata [2], however, in this study, acetogenins were not observed in the DART-MS spectrum probably due to their poor water solubilities.

\section{CONCLUSION}

The cytotoxic effect of the aqueous extract of $A$. muricata leaf against HeLa cells as well as its antioxidant activity lend some support for its traditional use as an anticancer remedy. However, additional long-term investigations are necessary to ascertain this. Its observed activities may be due to the water-soluble compounds such as alkaloids and phenols compounds. Furthermore, the aqueous extract contains carbohydrates, vitamins $\mathrm{C}$, vitamin $\mathrm{A}$, and $\mathrm{Na}$. Thus, it is also a potential nutritional supplement for human use.

\section{DECLARATIONS}

\section{Acknowledgement}

The authors thank widely to "Consejo Nacional de Ciencia y Tecnología (CONACYT)" of Mexico for the scholarship awarded to Ana V. CoriaTéllez (328341). We are grateful to Cynthia Ayala for her comments on the translation of this manuscript and to Luis Rojas for technical support.

\section{Conflict of Interest}

No conflict of interest associated with this work.

\section{Contribution of Authors}

The authors declare that this work was done by the authors named in this article and all liabilities pertaining to claims relating to the content of this article will be borne by them.

\section{REFERENCES}

1. Badrie N, Schauss AG. Soursop (Annona muricata L.): Composition, nutritional value, medicinal uses, and toxicology. Bioact Food Promot Heal 2009: 621-643.

2. Coria-Téllez AV, Montalvo-González E, Yahia EM, Obledo-Vázquez EN. Annona muricata: $A$ comprehensive review on its traditional medicinal uses, phytochemicals, pharmacological activities, mechanisms of action and toxicity. Arab J Chem 2018; (11): 662-691.

3. Leboeuf M, Legueut C, Cavé A, Desconclois JF, Forgacs $P$, Jacquemin $H$. Alkaloids of Annonaceae. XXIX. Alkaloids of Annona muricata. Planta Med 1981; 42(5): 37-44.

4. George VC, Kumar DRN, Suresh PK, Kumar, RA. Antioxidant, DNA protective efficacy and HPLC analysis of Annona muricata (soursop) extracts. J Food Sci Technol 2014: 1-8.

5. Nawwar M, Ayoub N, Hussein S, Hashim A, El-Sharawy $R$, Wende, $K$, Lindequist $U$. A flavonol triglycoside and investigation of the antioxidant and cell stimulating activities of Annona muricata Linn. Arch Pharm Res 2012; 35(5):761-767.

6. Singh A, Bajpai $V$, Srivastava $M$, Arya KR, Kumar $B$. Rapid screening and distribution of bioactive compounds in different parts of Berberis petiolaris using direct analysis real time mass spectrometry. $J$ Pharm Anal 2015: 5-8.

7. Wang L, Zeng S, Chen T, Qu H. Direct analysis in real time mass spectrometry, a process analytical technology tool for real-time process monitoring in botanical drug manufacturing. J Pharm Biomed Anal 2014; 91: 202-209.

8. Ménan H, Banzouzi JT, Hocquette A, Pélissier Y, Blache $Y$, Koné $M$, Valentin $A$. Antiplasmodial activity and cytotoxicity of plants used in West African traditional medicine for the treatment of malaria. J Ethnopharmacol 2006; 105: 131-136.

9. Asare G, Afriyie $D$, Ngala $R$, Abutiate $H$, Doku $D$, Mahmood S, Rahman H. Antiproliferative activity of aqueous leaf extract of Annona muricata $L$. on the prostate, $\mathrm{BPH}-1 \mathrm{Cells}$, and some target genes. Integr Cancer Ther 2014; 14(1): 65-74.

10. Astirin OP, Artanti AN, Fitria MS, Perwitasari EA, Prayitno A. Annonaa muricata Linn leaf induce apoptosis in cancer cause virus. J Cancer Ther 2013; 4: 1244-1250.

11. Hamad I, Erol-Dayi Ö, Pekmez M, Önay-Uçar E, Arda N. Antioxidant and cytotoxic activities of Aphanes arvensis extracts. Plant Foods Hum Nutr 2010; 65: 44-49 
12. AOAC. (1984). Offical methods of Analysis (14th ed). Washington $D C$

13. Suyatmi, Suselo YH, Jusuf SA. The selective cytotoxicity of ethanolic extract of Annona muricata leaf on HeLa cervical cancer cells. Altern Med Heal Care 2012: 22 23.

14. Champy P, Melot A, Guérineau V, Gleye C, Fall $D$, Höglinger GU, Hocquemiller R. Quantification of acetogenins in Annona muricata linked to atypical Parkinsonism in Guadeloupe. Mov Disord 2005; 20 : 1629-1633.

15. Pieme C, Kumar S, Dongmo M, Moukette B, Boyoum F, Ngogang J, Saxena A. Antiproliferative activity and induction of apoptosis by Annona muricata (Annonaceae) extract on human cancer cells. CAM 2014; 14(1): 516.

16. Gavamukulya $Y$, Abou-Elella F, Wamunyokoli $F$, AEIShemy H. Phytochemical screening, anti-oxidant activity and in vitro anticancer potential of ethanolic and water leaves extracts of Annona muricata (Graviola). Asian Pac J Trop Med 2014; 7: S355-S363

17. Mohanty S, Hollinshead J, Jones L, Jones PW, Thomas D, Watson Aa, Nash RJ. Annona muricata (Graviola): toxic or therapeutic. Nat Prod Commun 2008; 3(1):3133.

18. Fofana S, Ziyaev R, Abdusamatov A, Zakirov $S K$. Alkaloids from Annona muricata leaves. Chem Nat Compd 2011; 47(2): 321

19. Fofana S, Keita A, Balde S, Ziyaev R, Aripova SF. Alkaloids from leaves of Annona muricata. Chem Nat Compd 2012; 48(4): 714.

20. Stévigny C, Bailly C, Quetin-Leclercq J. Cytotoxic and antitumor potentialities of aporphinoid alkaloids. Curr Med Chem Anticancer Agents 2005; 5(2): 173-182.
21. Marques V, Farah A. Chlorogenic acids and related compounds in medicinal plants and infusions. Food Chem 2009; 113(4): 1370-1376.

22. Bajpai V, Pandey R, Negi MPS, Kumar N, Kumar B. $D A R T$ MS based chemical profiling for therapeutic potential of Piper betle Landraces. Nat Prod Commun 2013; 7(12): 1627-1629.

23. Jiménez VM, Gruschwitz M, Schweiggert RM, Carle R, Esquivel $P$. Identification of phenolic compounds in soursop (Annona muricata) pulp by high-performance liquid chromatography with diode array and electrospray ionization mass spectrometric detection. Food Res Int 2014; 65: 42-46.

24. Crawford, E., Goguen, R., \& Musselman, B. Direct Analysis in Real Time (DART (B)) Ambient lonization as a Tool for Rapid Screening and Characterization of Black Cohosh (Actaea racemosa) and other herbal products by MS Fingerprinting. 2013 [cited 2017 may 26]. Available from: http://www.ionsense.com/pdfs/ ICSB2013.pdf

25. Novotná H, Kmiecik O, Gałązka M, Krtková V, Hurajová A, Schulzová V, Hajšlová J. Metabolomic fingerprinting employing DART-TOFMS for authentication of tomatoes and peppers from organic and conventional farming. Food Addit Contam Part A 2012; 29(9): 1335-1346.

26. Rajchl A, Prchalová J, Rudolf Š, Helena Č. Evaluation of ice-tea quality by DART-TOF / MS. J Mass Spectrom 2015: 1214-1221.

27. Chernetsova ES, Crawford, EA, Shikov $A N$, Pozharitskaya ON, Makarov VG, Morlock GE. ID-CUBE direct analysis in real time high-resolution mass spectrometry and its capabilities in the identification of phenolic components from the green leaves of Bergenia crassifolia L. Rapid Commun Mass Spectrom 2012: 1329-1337. 